\title{
Effective Removal of Lead Ions from Aqueous Solution Using Nano Illite/Smectite Clay: Isotherm, Kinetic, and Thermodynamic Modeling of Adsorption
}

\author{
Juan Yin ${ }^{1,2}$, Chaobing Deng ${ }^{1,3, *}$, Zhen Yu ${ }^{4}$, Xiaofei Wang ${ }^{3}$ and Guiping $X u^{1,3}$ \\ 1 College of Light industry and Food Engineering, Guangxi University, Nanning 530004, China; \\ yinjuan101@163.com (J.Y.); xuguiping@126.com (G.X.) \\ 2 Department of Management Science and Engineering, Guangxi University of Finance and Economics, \\ Nanning 530003, China \\ 3 Guangxi Zhuang Autonomous Region Environmental Monitoring Center, Nanning 530028, China; \\ wangxiaofei26@163.com \\ 4 College of Resources, Enviroment and Materials, Guangxi University, Nanning 530004, China; \\ yz2465@hotmail.com \\ * Correspondence: dcb715@sina.com; Tel.: +86-771-532-5805
}

Received: 14 January 2018; Accepted: 13 February 2018; Published: 16 February 2018

\begin{abstract}
Illite-smectite clay is a new mixed mineral of illite and montmorillonite. The ability of nano illite/smectite clay to remove $\mathrm{Pb}$ (II) from slightly polluted aqueous solutions has been investigated. The effects of $\mathrm{pH}$, contact time, initial concentration of $\mathrm{Pb}(\mathrm{II})$, nano illite/smectite clay dosage, and temperature on the adsorption process were studied. The nano illite/smectite clay was characterized by X-Ray Diffraction (XRD), Fourier transform infrared spectrometry (FTIR), and Scanning electron microscopy (SEM). The results showed that $\mathrm{Pb}(\mathrm{II})$ was adsorbed efficiently by nano illite/smectite clay in aqueous solution. The pseudo-second-order kinetic model best described the kinetic of the adsorption, and the adsorption capacity of nano illite/smectite (I-S $\mathrm{S}_{\mathrm{m}}$ ) clay was found to be $256.41 \mu \mathrm{g} \cdot \mathrm{g}^{-1}$ for $\mathrm{Pb}$ (II). The adsorption patterns followed the Langmuir isotherm model. Thermodynamic parameters, including the Gibbs free energy $(\Delta \mathrm{G})$, enthalpy $(\Delta \mathrm{H})$, and entropy $(\Delta S)$ changes, indicated that the present adsorption process was feasible, spontaneous, and endothermic in the temperature range of $298-333 \mathrm{~K}$.
\end{abstract}

Keywords: $\mathrm{Pb}$ (II); nano illite/smectite clay; adsorption kinetics; adsorption thermodynamic

\section{Introduction}

Water is a source of life. In recent years, a large number of studies have indicated that the water, especially of rivers, in urban areas has been seriously contaminated by heavy metals [1-3]. Because heavy metals are not readily degradable in nature and accumulate in animals as well as human bodies, people who drink water or eat food containing heavy metals for a long time are susceptible to disease. Therefore, heavy metal contamination in the water environment has attracted great concern owing to its environmental toxicity and persistence.

Lead is a widely distributed and accumulative pollutant, and is the third-most common toxic element in the heavy metal toxicity list. It is also one of the 10 chemicals that the World Health Organization (WHO) has set out as a cause for significant public health concerns. Once the lead in the environment through various ways enters the human body and accumulates, the nerve, digestive, immune, and reproductive systems will be compromised and the health of human beings will be threatened, especially that of children $[4,5]$. The permissible limit for lead in potable water is $0.01 \mathrm{mg} \cdot \mathrm{L}^{-1}$ [6]. The removal of $\mathrm{Pb}(\mathrm{II})$ has become a great concern globally due to these toxic effects of $\mathrm{Pb}$ (II) on living beings. In the past few years, various techniques have been used, such as chemical 
precipitation, membrane filtration, ion exchange, and biological treatment, for lead removal [7-10]. Among these methods, adsorption has the advantages of being easy to perform and having a low cost and high efficiency. Thus, it has been used commonly in the heavy metal pollution treatment of water [11].

Clay as an adsorbent is widely used for the removal of heavy metals and has great applicability due to its being economical and having an environment-friendly nature, a high adsorption capacity, and a wide $\mathrm{pH}$ range [12,13]. In recent years, many kinds of clay, i.e., bentonite, kaolin, and montmorillonite, have been reported for the removal of high-concentration heavy metals from water [13-17]. Illite-smectite (I-S $\left.S_{m}\right)$ clay is a new mixed mineral of illite and montmorillonite, and a transition mineral from montmorillonite to illite, belonging to the typical 2:1-type layered silicate mineral. In 2014, nearly 30 billion tons of I- $S_{m}$ mineral was discovered in Shangsi County, Guangxi. Because I- $S_{m}$ mineral has the characteristics of high purity, fine particles, and a large surface area, I- $S_{m}$ has been studied for use as a rubber modifier [18] and as an adsorbent to remove high concentrations of heavy metals from aqueous solution $[19,20]$. Only a few studies have focused on the adsorption of low concentrations of heavy metals in contaminated water using I- $S_{m}$.

In this study, the I- $S_{m}$ mineral was first made nano-size, then nano I- $S_{m}$ was used to adsorb $\mathrm{Pb}(\mathrm{II})$ in a solution close to that of real polluted water. The effects of various analytical conditions, such as initial $\mathrm{pH}$ of the solution, contact time, and initial adsorbate and adsorbent concentration, were evaluated in detail on the removal performance of nano $\mathrm{I}-\mathrm{S}_{\mathrm{m}}$. Isotherm, kinetic, and thermodynamic modeling of the adsorption process was analyzed.

\section{Materials and Methods}

\subsection{Preparation of Nano $I-S_{m}$}

I-S $S_{m}$ mineral was provided by Sino-nanotech Holdings Co., Ltd. (Shangsi, Guangxi, China). The main steps of nano I-S $S_{m}$ preparation included crushing, soaking, dispersing, sieving and purification, and ultrafine grinding $[18,21]$. In detail, the preparation was as follows. Firstly, I- $S_{m}$ mineral was crushed into small pieces $(\mathrm{d}<2 \mathrm{~cm})$ and then soaked in a certain amount of water (the water-to-clay ratio was 9:11) for about $10 \mathrm{~h}$. Secondly, the soaked I-S $\mathrm{m}$ mud was dispersed for $30 \mathrm{~min}$ with a mixer beater and then passed through a 100-mesh and 325-mesh vibrating screen to obtain the primary nano I-S $\mathrm{S}_{\mathrm{m}}$ slurry $(\mathrm{d}<45 \mu \mathrm{m})$. Thirdly, the slurry was ground by a high energy density medium stirring mill (FPML OML-H/V, Buhler Group Co., Uzwil, Switzerland) for $2 \mathrm{~h}$. Finally, the slurry was dried by azeotropic distillation and then dispersed by high-speed mill.

\subsection{Characterization of Nano I-S}

The Fourier transform infrared (FT-IR) spectra of nano I- $\mathrm{S}_{\mathrm{m}}$ were recorded with the Fourier transform infrared spectrophotometer (Nicolet 380, Thermo Fisher, Waltham, MA, USA). The X-ray diffraction (XRD) analysis was determined using a MiniFlex X-ray diffractometer (Miniflex 600, Rigaku, Tokyo, Japan), and the scanning regions of the diffraction were $5-80^{\circ}$ on the $2 \theta$ angle. The morphology of nano I- $S_{m}$ was analyzed by a scanning electron microscope (SEM) (ProX, Phenom World, Shanghai, China), The Brunauer-Emmett-Teller (BET) surface area and pore properties of nano I-S $S_{m}$ were determined via $\mathrm{N}_{2}$ adsorption-desorption isotherms using a Micromeritics analyzer (ASAP 2460, Micromeritics, Norcross, GA, USA). The cation exchange capacity (CEC) of nano I-S $S_{m}$ was determined by the ammonium acetate method [22]. The slurry's $\mathrm{pH}$ was determined by soaking $1 \mathrm{~g}$ of nano I-S $\mathrm{m}$ in $50 \mathrm{~mL}$ distilled water, stirring the solution for $24 \mathrm{~h}$, filtering it, and then measuring the final $\mathrm{pH}$ [23].

\subsection{Batch Adsorption Experiments}

Stock solutions of $\mathrm{Pb}$ (II) were prepared by dissolving appropriate amounts of $\left(\mathrm{CH}_{3} \mathrm{COO}\right)_{2} \mathrm{~Pb} \cdot 3 \mathrm{H}_{2} \mathrm{O}$ in distilled water. Batch adsorption experiments were carried out in a series of centrifuge tubes by mixing a constant amount of nano I- $\mathrm{S}_{\mathrm{m}}$ with $40 \mathrm{~mL}$ of the aqueous solution of $\mathrm{Pb}$ (II) at varying concentration 
and different temperatures. Then, the centrifuge tubes were put in a shaker incubator at $150 \mathrm{rpm}$ for a certain time interval, the nano I-S $S_{m}$ was separated from the aqueous solutions by centrifugation at $3000 \mathrm{rpm}$ for $5 \mathrm{~min}$ (TDZ5-WS, Cence, Changsha, China), and the supernatant was filtered through a $0.45 \mu \mathrm{m}$ filter membrane. $\mathrm{Pb}$ (II) concentration in the solutions was measured by inductively coupled plasma mass spectrometry (7700 e, Agilent Technologies, Santa Clara, CA, USA).

The adsorption capacity of $\mathrm{Pb}(\mathrm{II})$ on nano $\mathrm{I}-\mathrm{S}_{\mathrm{m}}$ in the batch test was calculated using Equations (1) and (2).

$$
\begin{aligned}
R_{\text {ratio }} & =\frac{C_{0}-C_{e q}}{C_{0}} \times 100 \% \\
Q_{e} & =\frac{\left(C_{0}-C_{e q}\right) V}{m}
\end{aligned}
$$

where $R_{\text {ratio }}$ is the $\mathrm{Pb}(\mathrm{II})$ removal rate; $Q_{e}$ is the equilibrium capacity of lead on the nano I-S $\mathrm{S}_{\mathrm{mg}} \mathrm{mg} \mathrm{g}^{-1}$; $C_{0}$ is the initial concentration of the $\mathrm{Pb}$ (II) solution, $\mathrm{mg} \cdot \mathrm{L}^{-1} ; C_{e q}$ is the equilibrium concentration of the $\mathrm{Pb}$ (II) solution, $\mathrm{mg} \cdot \mathrm{L}^{-1} ; V$ is the solution volume, $\mathrm{L}$; and $m$ is the mass of nano I-S $\mathrm{m}, \mathrm{g}$. All assays were carried out in triplicate and only mean values are presented.

The effects of process variables, including $\mathrm{pH}$ of the solution, initial concentration of $\mathrm{Pb}(\mathrm{II})$, contact time, adsorbent dosage, and temperature, on the adsorption were studied. The $\mathrm{pH}$ of the solution at the start of the experiments was adjusted with $0.1 \mathrm{mg} \cdot \mathrm{L}^{-1} \mathrm{HCl}$ or $0.1 \mathrm{mg} \cdot \mathrm{L}^{-1} \mathrm{NaOH}$. Adsorption isotherms studies were conducted at 298, 308, 313, 323, and $333 \mathrm{~K}$, whereby $0.1 \mathrm{~g}$ of nano I-S $\mathrm{m}$ was kept in contact with $40 \mathrm{~mL}$ of $\mathrm{Pb}$ (II) solution of varying concentrations $(0.25,0.50,1.50,2.50,3.50$, and $\left.5 \mathrm{mg} \cdot \mathrm{L}^{-1}\right)$ at $\mathrm{pH}$. The kinetic experiments were performed using a $\mathrm{Pb}(\mathrm{II})$ concentration of $1 \mathrm{mg} \cdot \mathrm{L}^{-1}$ with $0.1 \mathrm{~g}$ nano $\mathrm{I}_{\mathrm{m}}$ at different time intervals $(5,10,20,30$, and $60 \mathrm{~min})$ at $\mathrm{pH} 5$.

\subsection{Theoretical Model}

\subsubsection{Adsorption Kinetics Model}

The equations of the pseudo-first-order [24] and the pseudo-second-order kinetic model [25] were used to fit experiment data obtained from the batch experiments. The formulas of the pseudo-first-order and the pseudo-second-order kinetic model are expressed as Equations (3) and (4), respectively.

$$
\begin{gathered}
\ln \left(Q_{e}-Q_{t}\right)=\ln Q_{e}-k_{1} t \\
\frac{t}{Q_{t}}=\frac{1}{k_{2} Q_{e}^{2}}+\frac{1}{Q_{e}} t
\end{gathered}
$$

where $Q_{t}$ is the amount of $\mathrm{Pb}(\mathrm{II})$ adsorbed at time $t, \mathrm{mg} \cdot \mathrm{g}^{-1}, k_{1}$ is the pseudo-first-order rate constant adsorption rate, $\min ^{-1}$; and $k_{2}$ is the adsorption rate constant in the pseudo-second-order kinetic rate constant, $\mathrm{g} \cdot \mu \mathrm{g}^{-1} \cdot \mathrm{min}^{-1}$.

\subsubsection{Adsorption Equilibrium}

The isotherm models of Langmuir [26] and Freundlich [27] were tested to analyze the equilibrium data. The Langmuir isotherm model and Freundlich isotherm model equations are expressed by Equations (5) and (6).

$$
\begin{gathered}
\frac{C_{e q}}{Q_{e}}=\frac{1}{Q_{\max }} C_{e q}+\frac{1}{Q_{\max } K_{L}} \\
\ln Q_{e}=\ln K_{f}+\frac{1}{n} \ln C_{e q}
\end{gathered}
$$

where $Q_{\text {max }}$ is the monolayer capacity of nano $\mathrm{I}-\mathrm{S}_{\mathrm{m}}, \mathrm{mg} \cdot \mathrm{g}^{-1} ; K_{\mathrm{L}}$ is the Langmuir constant, $\mathrm{L} \cdot \mu \mathrm{g}^{-1} ; K_{f}$ is the Freundlich constant, $\mu \mathrm{g} \cdot \mathrm{g}^{-1}$; and $n$ is the heterogeneity. 


\subsubsection{Adsorption Thermodynamics}

The thermodynamic parameters can be determined using the equilibrium constant and temperature $[28,29]$. The change in the Gibbs free energy $(\Delta \mathrm{G})$, enthalpy $(\Delta \mathrm{H})$, and entropy $(\Delta \mathrm{S})$ in the adsorption process was calculated using Equations (7) and (8).

$$
\begin{gathered}
\Delta \mathrm{G}=-R T \ln K_{d} \\
\ln K_{d}=\frac{\Delta \mathrm{S}}{R}-\frac{\Delta \mathrm{H}}{R T}
\end{gathered}
$$

where $R$ is the universal gas constant, $8.314 \mathrm{~J} \cdot \mathrm{mol}^{-1} \cdot \mathrm{K}^{-1} ; T$ is the absolute temperature, $\mathrm{K}$; and $K_{d}$ is the distribution coefficient of nano I-S $S_{\mathrm{m}}, K_{d}=Q_{e} / C_{e q}$.

\section{Results}

\subsection{Characterization of Nano I-S}

The chemical composition and physicochemical properties of nano I-S $\mathrm{S}_{\mathrm{m}}$ are presented in Table 1. The XRD patterns of nano I-S $S_{m}$ are given in Figure 1 A. Nano $I-S_{m}$ is mainly composed of quartz, mixed-layer illite/smectite, illite, and kaolinite, and the characteristic diffraction peak of nano I-S $\mathrm{m}$ was observed between 5 and $10^{\circ}(2 \theta)$ [30]. Furthermore, an FT-IR analysis was applied to identify the functional groups on the nano I- $S_{m}$ sample's surface. The FT-IR spectra of the nano I-S $S_{m}$ sample are shown in Figure 1B. The absorption bands at 3698.96 and $3620.60 \mathrm{~cm}^{-1}$ represent the inner surface $\mathrm{OH}$ stretching vibration, while the absorption band at $3423.76 \mathrm{~cm}^{-1}$ represents the outer surface $\mathrm{OH}$ stretching vibration. These $\mathrm{OH}$ groups function as an active site for the binding of positively charged cations. The absorption band at $1629.97 \mathrm{~cm}^{-1}$ represents the $\mathrm{OH}$ bending of water retained in the silica matrix [23]. The absorption bands at 1031.99 and $470.19 \mathrm{~cm}^{-1}$ represent the $\mathrm{Si}-\mathrm{O}-\mathrm{Si}$ stretching vibration [31]. The absorption band at $912.4 \mathrm{~cm}^{-1}$ represents the $\mathrm{Al}-\mathrm{OH}$ bending vibrations [29], while those at 798.04 and $694.4 \mathrm{~cm}^{-1}$ represent the Si-O stretching vibration [23].

Table 1. Chemical composition and physicochemical properties of nano illite-smectite (I-S $\left.\mathrm{S}_{\mathrm{m}}\right)$ clay.

\begin{tabular}{cc}
\hline Parameter & Value \\
\hline $\mathrm{SiO}_{2}(\mathrm{wt} \%)$ & 64.29 \\
$\mathrm{Al}_{2} \mathrm{O}_{3}(\mathrm{wt} \%)$ & 20.38 \\
$\mathrm{Fe}_{2} \mathrm{O}_{3}(\mathrm{wt} \%)$ & 2.95 \\
$\mathrm{~K}_{2} \mathrm{O}(\mathrm{wt} \%)$ & 2.74 \\
$\mathrm{MgO}(\mathrm{wt} \%)$ & 1.82 \\
$\mathrm{TiO}_{2}(\mathrm{wt} \%)$ & 0.82 \\
$\mathrm{Na}_{2} \mathrm{O}(\mathrm{wt} \%)$ & 0.19 \\
Loss of ignition $\left(\mathrm{wt}^{2} \%\right)$ & 6.46 \\
$\mathrm{BET}$ surface area $\left(\mathrm{m}^{2} \cdot \mathrm{g}^{-1}\right)$ & 39.46 \\
Micropore area $\left(\mathrm{m}^{2} \cdot \mathrm{g}^{-1}\right)$ & 10.46 \\
External surface area $\left(\mathrm{m}^{2} \cdot \mathrm{g}^{-1}\right)$ & 28.99 \\
Total pore volume $\left(\mathrm{cm}^{3} \cdot \mathrm{g}^{-1}\right)$ & 0.011 \\
Micropore volume $\left(\mathrm{cm}^{3} \cdot \mathrm{g}^{-1}\right)$ & 0.0055 \\
CEC (meg $/ 100 \mathrm{~g})$ & 1.07 \\
Slurry $\mathrm{pH}$ & 2.11 \\
\hline
\end{tabular}

CEC: cation exchange capacity. BET: Brunauer-Emmett-Teller. 

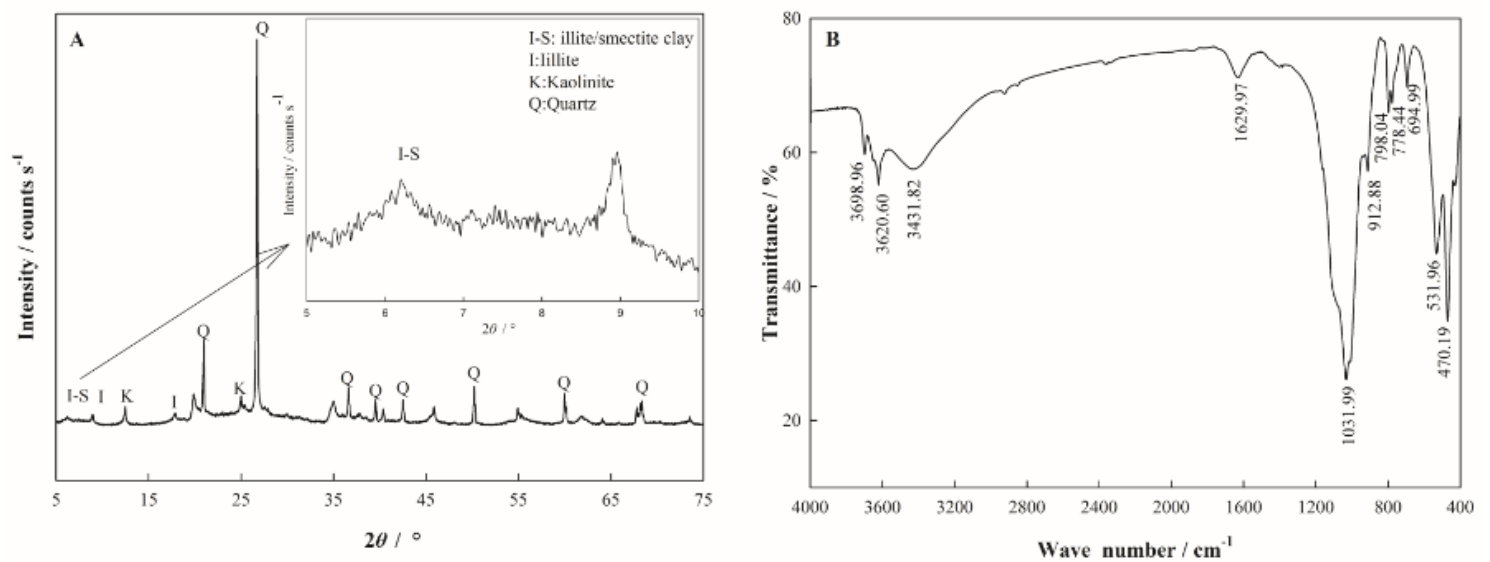

Figure 1. XRD spectra (A) and FT-IR spectrum (B) of nano $I-S_{m}$.

SEM analysis is another important tool used in the determination of the surface morphology of an adsorbent. In this study, SEM was used to probe the change in morphological features of nano I-S $\mathrm{m}$ and $\mathrm{Pb}$-adsorbed nano I-S $\mathrm{m}$ (Figure 2).

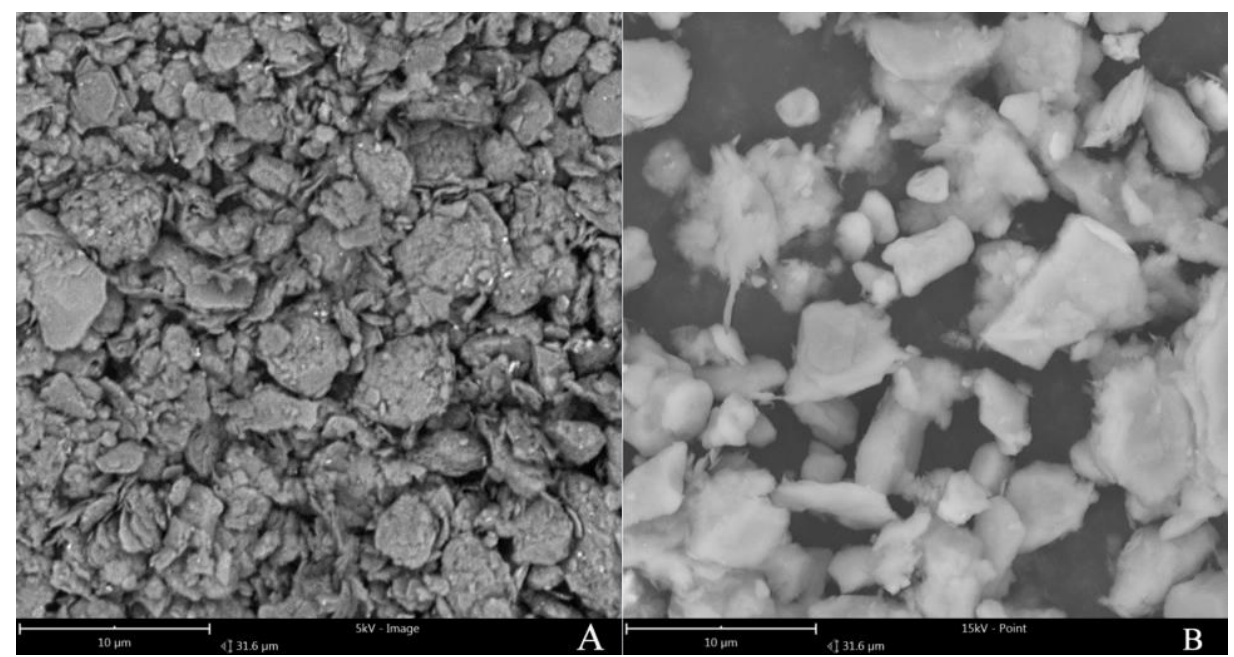

Figure 2. (A) SEM micrograph of nano $\mathrm{I}_{\mathrm{S}} \mathrm{S}_{\mathrm{m}}$ (before adsorption); (B) after $\mathrm{Pb}(\mathrm{II})$ adsorption.

\subsection{Effect of Adsorption Conditions}

\subsubsection{Effect of $\mathrm{pH}$}

The effect of $\mathrm{pH}$ on $\mathrm{Pb}$ (II) removal rate was investigated at $298 \mathrm{~K}$ for $60 \mathrm{~min}$ as shown in Figure $3 \mathrm{~A}$. It was observed that the levels of adsorption efficiency of $\mathrm{Pb}(\mathrm{II})$ increased significantly with increasing $\mathrm{pH}$. The removal rate of $\mathrm{Pb}(\mathrm{II})$ on nano $\mathrm{I}_{-} \mathrm{S}_{\mathrm{m}}$ was only $41.25 \%$ at $\mathrm{pH} 2.0$. In addition, the removal rate of $\mathrm{Pb}$ (II) tended to equilibrate at $\mathrm{pH}$ 4.0. When the solution had a $\mathrm{pH}>6.0$, the solution of $\mathrm{Pb}$ (II) gradually formed $\mathrm{Pb}(\mathrm{OH})_{2}$ precipitate, and the solution system became relatively complex. 

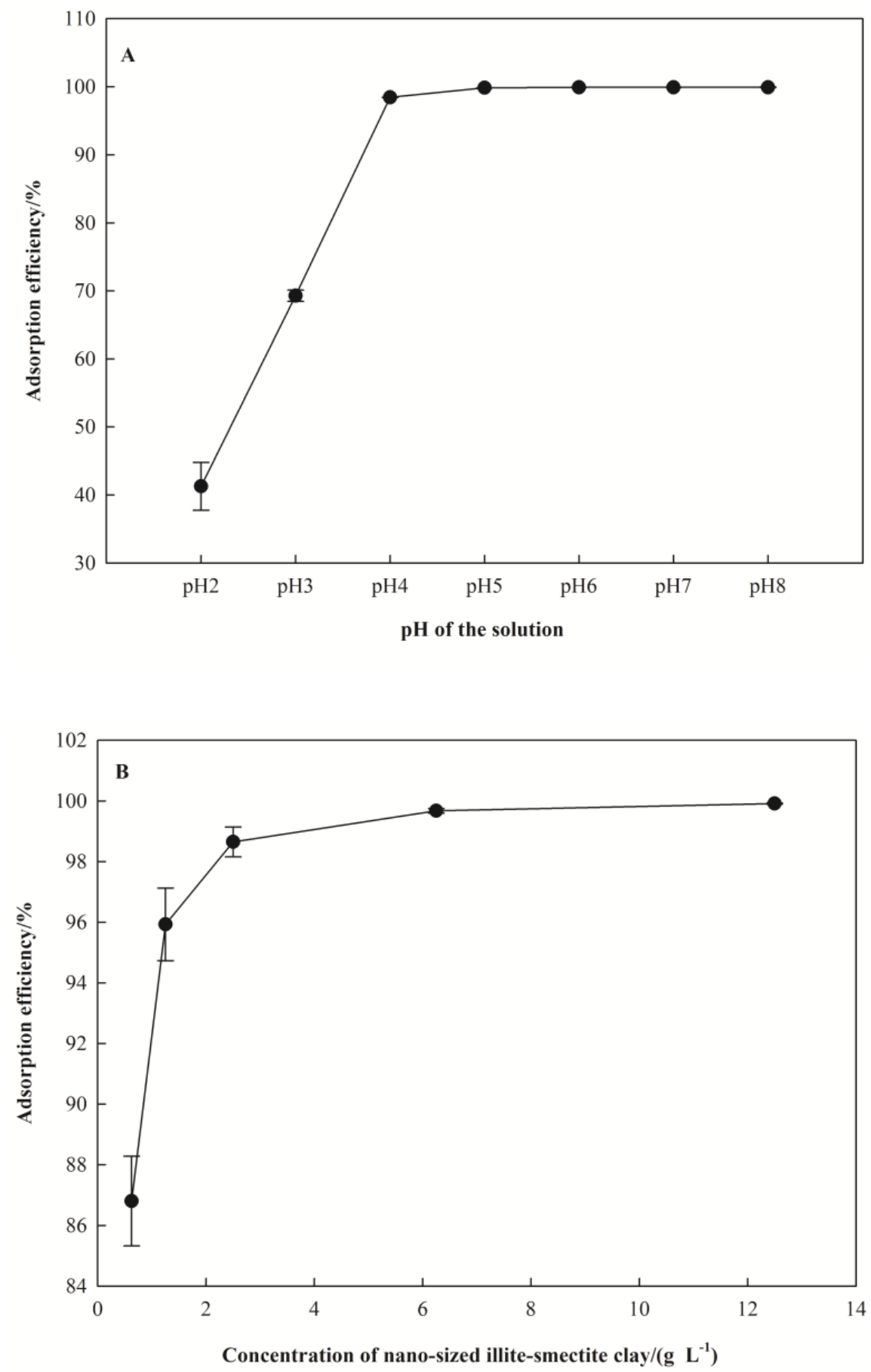

Figure 3. Cont. 

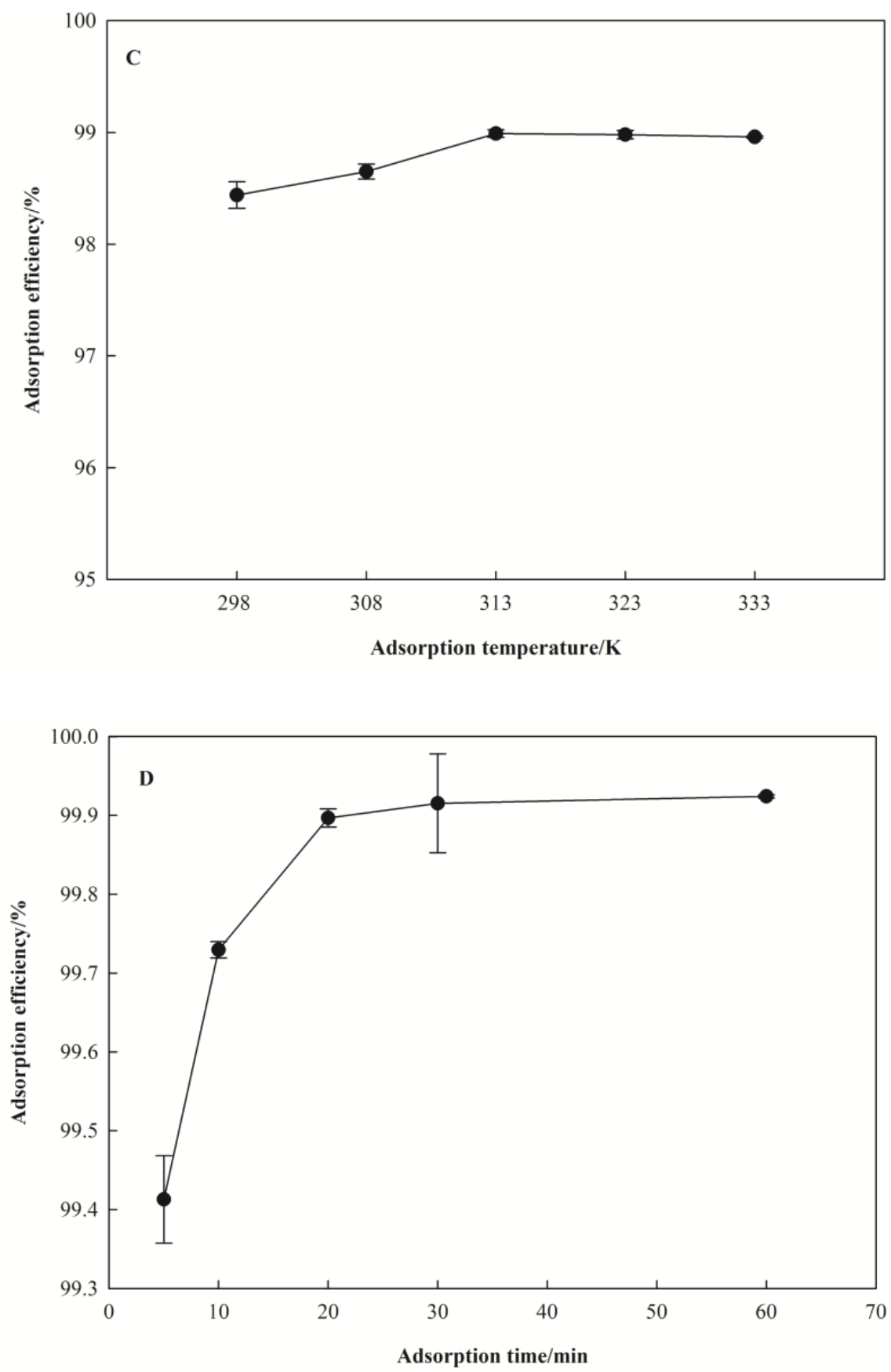

Figure 3. Cont. 


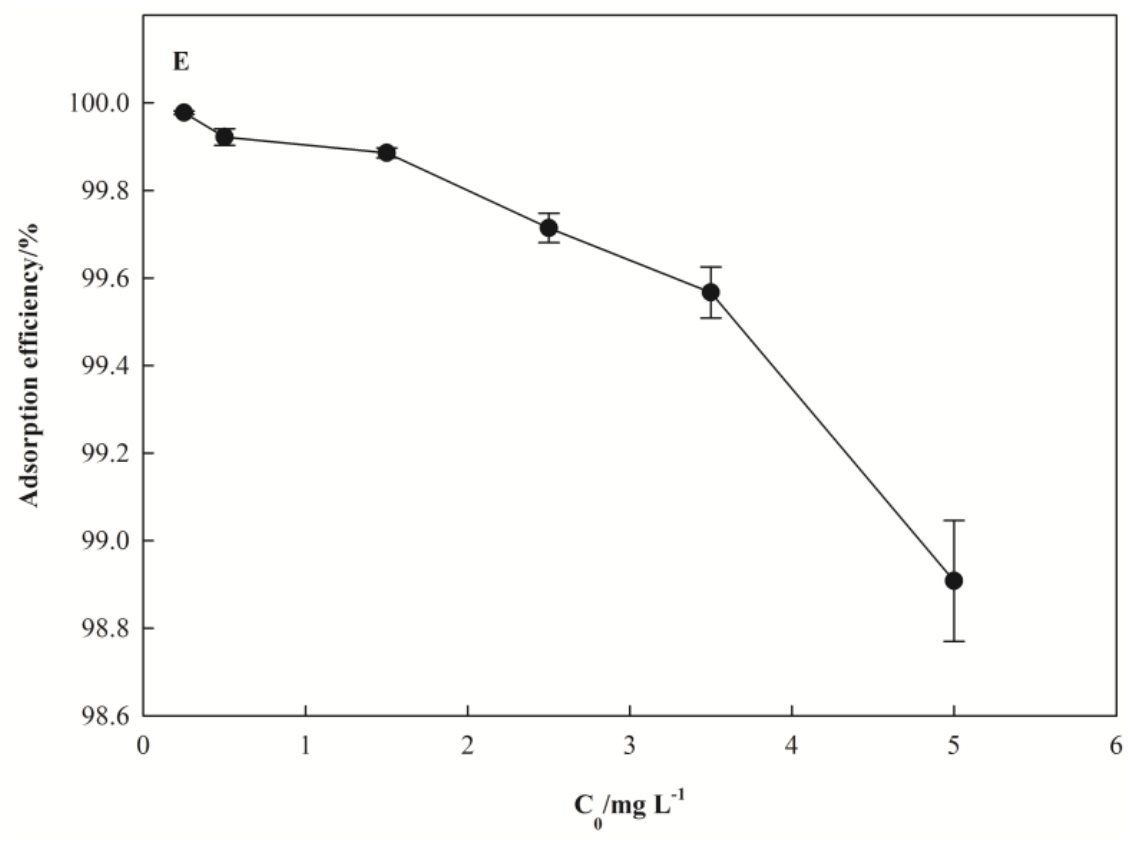

Figure 3. Effect of adsorption conditions on the removal rate of $\mathrm{Pb}(\mathrm{II})$. (A) for $\mathrm{pH}$, (B) for dosage of $\mathrm{I}_{-} \mathrm{S}_{\mathrm{m}},(\mathrm{C})$ for adsorption temperature, (D) for adsorption time, (E) for $\mathrm{Pb}$ (II) initial concentration.

\subsubsection{Effect of Nano I-S $\mathrm{m}$ Dosage}

The effect of nano I- $\mathrm{S}_{\mathrm{m}}$ dosage on $\mathrm{Pb}(\mathrm{II})$ removal rate is shown in Figure 3B. The nano $\mathrm{I}-\mathrm{S}_{\mathrm{m}}$ dosage varied from 0.625 to $12.5 \mathrm{~g} \cdot \mathrm{L}^{-1}$ with a constant initial $\mathrm{Pb}(\mathrm{II})$ concentration of $1 \mathrm{mg} \cdot \mathrm{L}^{-1}$ for $60 \mathrm{~min}$ at $298 \mathrm{~K}$. Figure 3B shows the effect of nano I- $\mathrm{S}_{\mathrm{m}}$ dosage on the removal rate of $\mathrm{Pb}(\mathrm{II})$. It was observed that the removal rate of $\mathrm{Pb}(\mathrm{II})$ increased with an increase in the nano I-S $\mathrm{S}_{\mathrm{m}}$ dosage from 0.625 to $2.5 \mathrm{~g} \cdot \mathrm{L}^{-1}$. A further increase in the nano I- $S_{m}$ dosage, however, did not result in a sufficient increase in the removal rate of $\mathrm{Pb}(\mathrm{II})$.

\subsubsection{Effect of Adsorption Temperature}

The effect of temperature on $\mathrm{Pb}(\mathrm{II})$ removal rate is shown in Figure 3C. It was observed that the removal rate of $\mathrm{Pb}$ (II) was $98.44-98.99 \%$ when the temperature was set at $298,308,313,323$, and $333 \mathrm{~K}$. The trend of the removal rate with the increase of temperature is not obvious.

\subsubsection{Effect of Adsorption Time}

The effect of adsorption time on the removal rate of $\mathrm{Pb}(\mathrm{II})$ is shown in Figure 3D. In a $\mathrm{Pb}(\mathrm{II})$ solution with a low initial concentration, the removal rate of $\mathrm{Pb}$ (II) in solution reached $99.41 \%$ when the adsorption time was $5 \mathrm{~min}$, and the removal rate of $\mathrm{Pb}(\mathrm{II})$ tended to be stable after $20 \mathrm{~min}$.

\subsubsection{Effect of Initial Concentration of $\mathrm{Pb}$ (II)}

The effect of initial concentration on the removal rate of $\mathrm{Pb}(\mathrm{II})$ adsorbed by nano $\mathrm{I}-\mathrm{S}_{\mathrm{m}}$ is shown in Figure 3E. The removal rate of $\mathrm{Pb}$ (II) decreased with the increase of initial $\mathrm{Pb}$ (II) concentration. When the initial concentration of $\mathrm{Pb}$ (II) increased from 0.25 to $5 \mathrm{mg} \cdot \mathrm{L}^{-1}$, the removal rate of $\mathrm{Pb}$ (II) decreased from $99.45 \%$ to $98.90 \%$.

\subsection{Kinetic Parameters of the Adsorption}

The kinetic of adsorption of $\mathrm{Pb}$ (II) on nano $\mathrm{I}-\mathrm{S}_{\mathrm{m}}$ was fitted by pseudo-first-order and pseudo-second-order kinetic equations. The results are shown in Table 2 and Figure 4. The correlation coefficient of the linear plots of $t / Q_{t}$ against $t$ for the pseudo-first-order model and the pseudo-second-order 
model was 0.985 and 1 , respectively. The $Q_{e}$ of the pseudo-first-order kinetics model was $2.603 \mu \mathrm{g} \cdot \mathrm{g}^{-1}$, and the $Q_{e}$ of pseudo-second-order dynamic model was $256.410 \mu \mathrm{g} \cdot \mathrm{g}^{-1}$.

Table 2. The predicted parameters by pseudo-first-order and pseudo-second-order kinetic models and experimental data.

\begin{tabular}{ccccccc}
\hline \multicolumn{2}{c}{ Pseudo-First-Order Kinetic Model } & \multicolumn{2}{c}{ Pseudo-Second-Order Kinetic Model } & \multicolumn{2}{c}{ Experimental Data } \\
\hline$k_{1} / \mathrm{min}^{-1}$ & $Q_{e} /\left(\mu \mathrm{g} \cdot \mathrm{g}^{-1}\right)$ & $R^{2}$ & $K_{2} /\left(\mu \mathrm{g} \cdot \mathrm{g}^{-1} \cdot \mathrm{min}^{-1}\right)$ & $Q_{e} /\left(\mu \mathrm{g} \cdot \mathrm{g}^{-1}\right)$ & $R^{2}$ & $Q_{e} /\left(\mu \mathrm{g} \cdot \mathrm{g}^{-1}\right)$ \\
\hline 0.380 & 2.603 & 0.985 & 0.251 & 256.410 & 1.000 & 254.680 \\
\hline
\end{tabular}

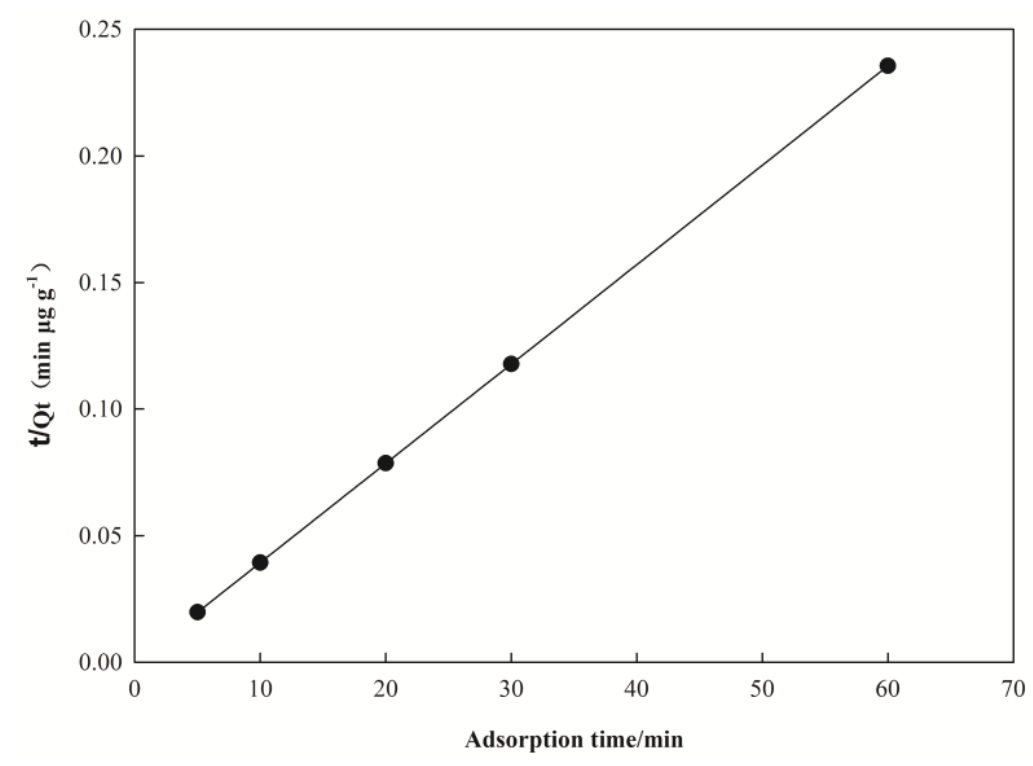

Figure 4. Pseudo-second-order plots for the adsorption of $\mathrm{Pb}(\mathrm{II})$ at $298 \mathrm{~K}$.

\subsection{Equilibrium Parameters of the Adsorption}

The Langmuir and Freundlich isotherm models were used to analyze the adsorption of $\mathrm{Pb}$ (II) on nano I- $\mathrm{S}_{\mathrm{m}}$. All of the isotherm constants and correlation coefficients were calculated from the linear forms of the isotherm model equations and are provided in Table 3 and Figure 5.

Table 3. Parameters calculated by the Langmuir and Freundlich isotherm models for the adsorption of $\mathrm{Pb}(\mathrm{II})$ on nano I-Sm.

\begin{tabular}{cccccc}
\hline & Langmuir & \multicolumn{3}{c}{ Freundlich } \\
\hline $\mathrm{Q}_{\max } /\left(\mathrm{mg} \cdot \mathrm{g}^{-1}\right)$ & $K_{\mathrm{L}} /\left(\mathrm{L} \cdot \mu \mathrm{g}^{-1}\right)$ & $\mathrm{R}^{2}$ & $K_{f} /\left(\mu \mathrm{g} \cdot \mathrm{g}^{-1}\right)$ & $1 / n$ & $\mathrm{R}^{2}$ \\
\hline 2.104 & 0.216 & 0.985 & 8.825 & 0.457 & 0.980 \\
\hline
\end{tabular}




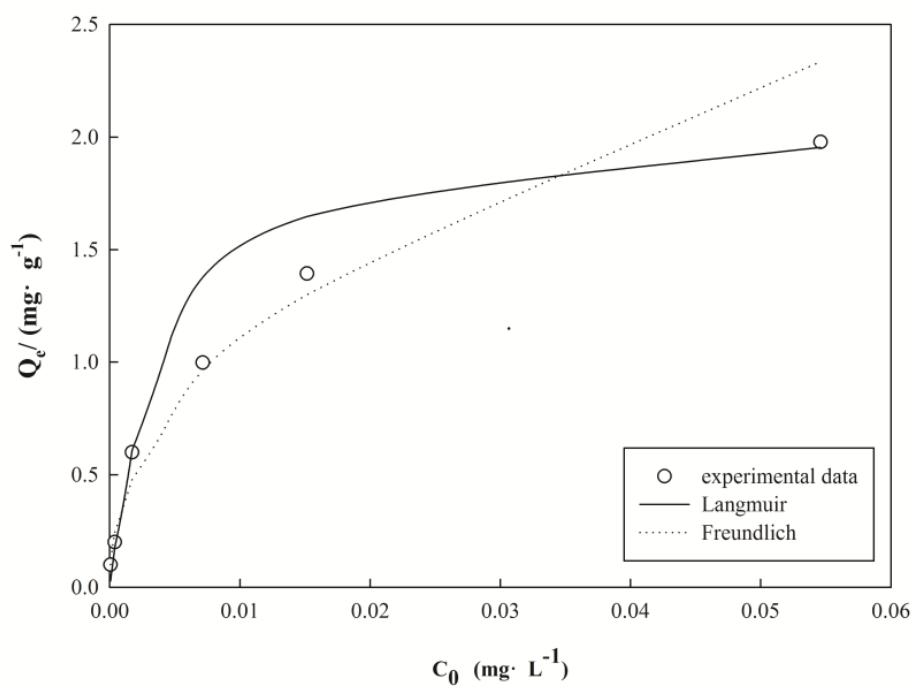

Figure 5. Comparison of equilibrium isotherms between the experimental data and the theoretical data.

\subsection{Thermodynamic Parameters of the Adsorption}

The results of the analysis of the thermodynamic parameters of adsorption are shown in Table 4 and Figure 6.

Table 4. Thermodynamic parameters for adsorption of $\mathrm{Pb}^{2+}$ on nano I- $\mathrm{S}_{\mathrm{m}}$.

\begin{tabular}{ccccccc}
\hline$\Delta \mathbf{S}$ & $\Delta \mathbf{H}$ & \multicolumn{5}{c}{$\Delta \mathrm{G} / \mathbf{( k J} \cdot \mathbf{m o l} \mathbf{- 1}^{-\mathbf{~}}$} \\
\hline $\mathrm{J} / \mathrm{mol}^{-1} \cdot \mathrm{K}^{-1}$ & $\mathrm{~kJ} \cdot \mathrm{mol}^{-1}$ & $298 \mathrm{~K}$ & $308 \mathrm{~K}$ & $313 \mathrm{~K}$ & $323 \mathrm{~K}$ & $333 \mathrm{~K}$ \\
\hline 9.658 & 4.844 & -2.541 & -2.637 & -2.695 & -2.788 & -2.876 \\
\hline
\end{tabular}

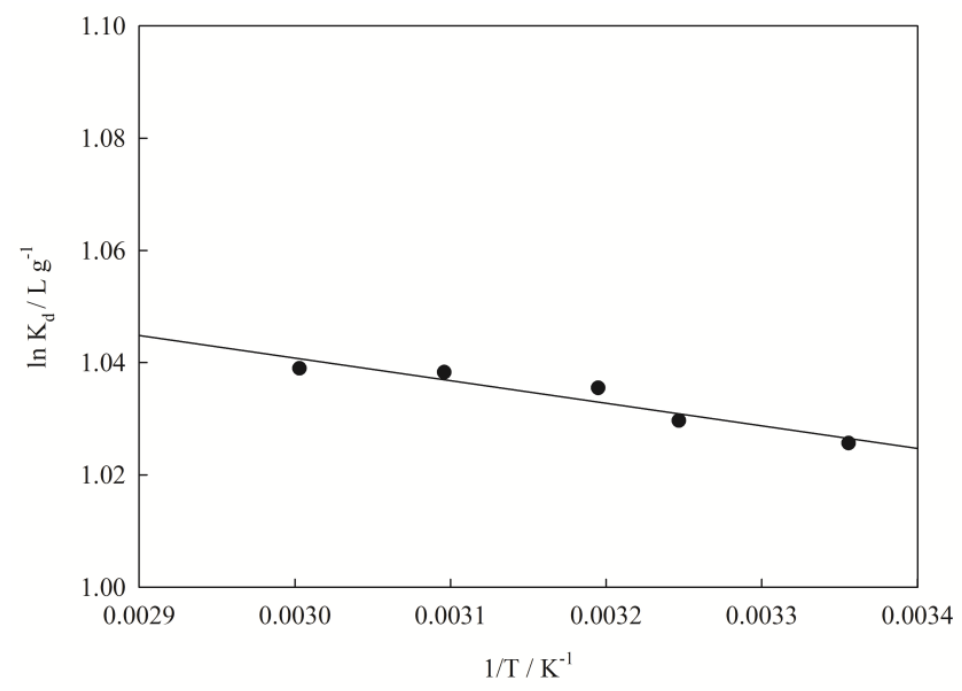

Figure 6. Relationship between $1 / T$ and $\ln K_{d}$ for nano I-S $S_{\mathrm{m}}$.

\section{Discussion}

Among the adsorption conditions, the $\mathrm{pH}$ of the aqueous solution is an important variable for the adsorption of metals onto the adsorbents [32]. In this study, the adsorption efficiency was significantly inhibited when the $\mathrm{pH}$ of the aqueous solution was low. At a low $\mathrm{pH}$, the number of $\mathrm{H}^{+}$ions exceeds that of $\mathrm{Pb}(\mathrm{II})$ ions several times and the surface of nano $\mathrm{I}_{-} \mathrm{S}_{\mathrm{m}}$ is most likely covered with $\mathrm{H}^{+}$ions, 
which account for less $\mathrm{Pb}(\mathrm{II})$ adsorbed [33]. As the $\mathrm{pH}$ increases, more and more $\mathrm{H}^{+}$ions leave the nano $\mathrm{I}-\mathrm{S}_{\mathrm{m}}$ surface, making the sites available to the $\mathrm{Pb}(\mathrm{II})$, which could increasingly bind to the nano I- $S_{m}$ surface through a mechanism similar to that of exchange interactions $(\mathrm{H}(\mathrm{I}) / \mathrm{Pb}(\mathrm{II}))$ [28]. In the meantime, Yuan et al. [19] have found that the Zeta potential decreased from 3.29 to $-69.95 \mathrm{mV}$ when the $\mathrm{pH}$ value increased from 2 to 7 in a nano $\mathrm{I}-\mathrm{S}_{\mathrm{m}}$ solution, indicating that the surface charge of the nano $\mathrm{I}-\mathrm{S}_{\mathrm{m}}$ changed from positive to negative, and further verifying the deprotonation processes of nano- $\mathrm{I}-\mathrm{S}_{\mathrm{m}}$ with the increase of $\mathrm{pH}$. It was observed that nano I- $\mathrm{S}_{\mathrm{m}}$ was suitable for removing $\mathrm{Pb}(\mathrm{II})$ from waste water under an acidic condition, which was similar to the results of some clay adsorbing heavy metals $[28,29]$. The removal rate of $\mathrm{Pb}$ (II) is also related to the I- $\mathrm{S}_{\mathrm{m}}$ dosage. At a lower nano I- $\mathrm{S}_{\mathrm{m}}$ dosage, $\mathrm{Pb}(\mathrm{II})$ ions compete for the limited adsorption sites in the nano I-S $\mathrm{m}$. As the quantity of nano $\mathrm{I}-\mathrm{S}_{\mathrm{m}}$ increased, more available sites promoted a greater percentage removal of $\mathrm{Pb}$ (II) [33]. When the amount of nano I-S $\mathrm{m}$ was $6 \mathrm{~g} \cdot \mathrm{L}^{-1}, 1 \mathrm{mg} \cdot \mathrm{L}^{-1} \mathrm{~Pb}(\mathrm{II})$ in solution would be reduced to $0.01 \mathrm{mg} \cdot \mathrm{L}^{-1}$, reaching the potable water standard. In addition, nano I- $\mathrm{S}_{\mathrm{m}}$ showed a rapid adsorption effect in the temperature range of $298-333 \mathrm{~K}$. The above results revealed an important advantage of high efficiency removal of $\mathrm{Pb}$ (II) by the nano I-S $\mathrm{S}_{\mathrm{m}}$.

The $Q_{e}$ of the pseudo-second-order dynamic model was much closer to the experimental result and the correlation coefficients were found to be relatively high. The pseudo-second-order adsorption mechanism was predominant for the adsorption of $\mathrm{Pb}(\mathrm{II})$ on nano $\mathrm{I}-\mathrm{S}_{\mathrm{m}}$. The pseudo-second-order model assumes that two reactions are happening: the first one is fast and reaches equilibrium quickly, whereas the second one is a slower reaction [15]. Accordingly, the following mechanism may be proposed [33]:

$$
\text { Clay }+\mathrm{Pb}(\mathrm{II})=\text { Clay } \cdots \mathrm{Pb}(\mathrm{II})
$$

in which the number of adsorption sites on the nano $\mathrm{I}-\mathrm{S}_{\mathrm{m}}$ surface and the number of $\mathrm{Pb}$ (II) ions in the liquid phase determine the kinetics. Depending on $\mathrm{pH}$, different $\mathrm{Pb}$-species may be held to the clay surface at appropriate ion-exchange sites $[25,33]$.

The correlation coefficient of the Langmuir isotherm model was higher than that of the Freundlich isothermal model, from which we can conclude that the Langmuir isotherm model was more suitable for nano I- $\mathrm{S}_{\mathrm{m}}$ removal of $\mathrm{Pb}(\mathrm{II})$ in aqueous solutions. Similar results were also reported in earlier studies in which the adsorption of heavy metal ions fitted well to the Langmuir isotherm $[15,19,33]$. Furthermore, the $n$ values of the Freundlich isothermal model relate to the adsorption properties of the adsorbent, where values of $n$ between 2 and 10 represent good adsorption [34], which is an indication of the good adsorption of $\mathrm{Pb}(\mathrm{II})$ by nano $\mathrm{I}-\mathrm{S}_{\mathrm{m}}$.

The Gibbs free energy $(\Delta \mathrm{G})$ was $-2.541,-2.637,-2.695,-2.788$, and $-2.876 \mathrm{~kJ} \mathrm{~mol}^{-1}(\Delta \mathrm{G}<0)$ when the temperature was set at 298, 308,313,323, and $333 \mathrm{~K}$, respectively. These indicate that the adsorption of $\mathrm{Pb}$ (II) on nano I- $\mathrm{S}_{\mathrm{m}}$ is a spontaneous process [23]. The $\Delta \mathrm{H}$ was $4.844 \mathrm{~kJ} \mathrm{~mol}^{-1}(0<\Delta \mathrm{H}<16)$, which indicates that the adsorption of $\mathrm{Pb}$ (II) on nano $\mathrm{I}-\mathrm{S}_{\mathrm{m}}$ is an endothermic process $[19,34]$.

The SEM results showed that the surface morphology of $\mathrm{Pb}$-adsorbed nano I- $\mathrm{S}_{\mathrm{m}}$ is different from that of natural nano I- $S_{m}$. The natural nano I- $S_{m}$ showed loose aggregates with a porous structure. After adsorption, the surface of nano I- $S_{m}$ demonstrates compacted aggregates. The surface morphology of the natural nano I- $S_{m}$ changed evidently during the adsorption process, indicating that significant interaction at the lead-clay interface occurred during the experiment. Similar SEM results were reported by other researchers [28,35].

\section{Conclusions}

As a new adsorbent, nano I-S $\mathrm{m}$ can be used for depth treatment in lead-contaminated water. The pseudo-second-order adsorption mechanism was predominant for the adsorption of $\mathrm{Pb}$ (II) on nano I- $S_{\mathrm{m}}$. The saturated adsorption capacity of $\mathrm{Pb}(\mathrm{II})$ on nano $\mathrm{I}-\mathrm{S}_{\mathrm{m}}$ in the aqueous solution was $256.41 \mu \mathrm{g} \cdot \mathrm{g}^{-1}$. The adsorption patterns followed the Langmuir isotherm model. The adsorption of $\mathrm{Pb}$ (II) on nano I- $\mathrm{S}_{\mathrm{m}}$ is a thermodynamically feasible, spontaneous, and endothermic process. 
Acknowledgments: This work was supported by the Guangxi Natural Science Foundation (grant No. 2015GXNSFEA139001) from the Guangxi science and Technology Department, the project of International Scientific Exchange Program (grant No. 7-1, 2017) from the Ministry of Science and Technology of the People's Republic of China, and the key project of Guangxi Social Sciences. (grant No. gxsk201605)

Author Contributions: Juan Yin and Chaobing Deng designed the study; Juan Yin and Zhen Yu analyzed the data; Juan Yin wrote the article, and Xiaofei Wang and Guiping Xu provided access to the experimental site.

Conflicts of Interest: The authors declare no conflict of interest.

\section{References}

1. Dipak, P. Research on heavy metal pollution of river Ganga: A review. Ann. Agrar. Sci. 2017, 15, $278-286$. [CrossRef]

2. IslamabMd, M.S.; Ahmed, M.K.; Raknuzzaman, M.; Mamun, M.H.-A.; Islam, M.K. Heavy metal pollution in surface water and sediment: A preliminary assessment of an urban river in a developing country. Ecol. Indic. 2015, 48, 282-291. [CrossRef]

3. Xie, X.J.; Wang, F.Y.; Wang, G.J.; Mei, R.W.; Wang, C.Z. Study on Heavy Metal Pollution in Surface Water in China. Envron. Sci. Manag. 2017, 42, 31-34. [CrossRef]

4. Zhang, X.W.; Yang, L.S.; Li, Y.H.; Li, H.R.; Wang, W.Y.; Ye, B.X. Impacts of lead / zinc mining and smelting on the environment and human health in China. Environ. Monit. Assess. 2012, 184, 2261-2273. [CrossRef] [PubMed]

5. Li, Z.Y.; Ma, Z.W.; Kuijp, T.J.; Yuan, Z.W.; Huang, L. A review of soil heavy metal pollution from mines in China: Pollution and health risk assessment. Sci. Total Environ. 2014, 468-469, 843-853. [CrossRef] [PubMed]

6. Ahmaruzzaman, M.; Gupta, V.K. Rice husk and its ash as low-cost adsorbents in water and wastewater treatment. Ind. Eng. Chem. Res. 2011, 50, 13589-13613. [CrossRef]

7. Zhao, D.D.; Yu, Y.; Chen, P. Treatment of lead contaminated water by a PVDF membrane that is modified by zirconium, phosphate and PVA. Water Res. 2016, 101, 564-573. [CrossRef] [PubMed]

8. Vergili, I.; Gönder, Z.B.; Kaya, Y.; Gürdağ, G.; Çavuş, S. Sorption of Pb (II) from battery industry wastewater using a weak acid cation exchange resin. Process Saf. Environ. Prot. 2017, 107, 498-507. [CrossRef]

9. Milind, M.N.; Santosh, K.D. Lead resistant bacteria: Lead resistance mechanisms, their applications in lead bioremediation and biomonitoring. Ecotox. Environ. Saf. 2013, 98, 1-7. [CrossRef]

10. Abreham, T.B.; Abaynesh, Y.G.; Ramato, A.T.; Dawit, N.; Efrem, C.; Lidietta, G. Removal of emerging micropollutants by activated sludge process and membrane bioreactors and the effects of micropollutants on membrane fouling: A review. J. Environ. Chem. Eng. 2017, 5, 2395-2414. [CrossRef]

11. Zhao, G.X.; Li, J.X.; Ren, X.M.; Chen, C.L.; Wang, X.K. Few-layered graphene oxide nanosheets as superior sorbents for heavy metal ion pollution management. Environ. Sci. Technol. 2011, 45, 10454-10462. [CrossRef] [PubMed]

12. Burakov, A.E.; Galunin, E.V.; Burakova, I.V.; Kucherova, A.E.; Agarwal, S.; Tkachev, A.G.; Gupta, V.K. Adsorption of heavy metals on conventional and nanostructured materials for wastewater treatment purposes: A review. Ecotoxicol. Environ. Saf. 2018, 148, 702-712. [CrossRef] [PubMed]

13. Mohammad, K.U. A review on the adsorption of heavy metals by clay minerals, with special focus on the past decade. Chem. Eng. J. 2017, 308, 438-462. [CrossRef]

14. Masindi, V.; Gitari, W.M. Simultaneous removal of metal species from acidic aqueous solutions using cryptocrystalline magnesite/bentonite clay composite: An experimental and modelling approach. J. Clean. Prod. 2016, 112, 1077-1085. [CrossRef]

15. Joziane, G.M.; Murilo, P.M.; Thirugnanasambandham, K.; Sergio, H.B.F.; Marcelino, L.G.; Maria, A.S.D.B.; Sivakumar, V. Preparation and characterization of calcium treated bentonite clay and its application for the removal of lead and cadmium ions: Adsorption and thermodynamic modeling. Process Saf. Environ. 2017, 111, 244-252. [CrossRef]

16. Sari, A.; Tuzen, M. Cd(II) adsorption from aqueous solution by raw and modified kaolinite. Appl. Clay Sci. 2014, 88-89, 63-72. [CrossRef]

17. Atta, A.M.; Al-Lohedan, H.A.; ALOthman, Z.A.; Abdel-Khalek, A.A.; Tawfeek, A.M. Characterization of reactive amphiphilic montmorillonite nanogels and its application for removal of toxic cationic dye and heavy metals water pollutants. J. Ind. Eng. Chem. 2015, 31, 374-384. [CrossRef] 
18. Qiu, J.Y. Preparation of Illite/Smectite Clay Nano-Powder and Its Application as Rubber Filler. Master's Thesis, South China University of Technology, Guangzhou, China, 4 June 2014.

19. Yuan, S.S.; Li, Z.Y.; Pan, Z.D.; Wang, Y.M. Removal of Copper and Cadmium Ions in Aqueous Solution via Adsorption by Nano-sized Illite-Smectite Clay. J. Chin. Ceram. Soc. 2016, 44, 43-49. [CrossRef]

20. Zhang, L.H.; Yuan, Y.H.; Yan, Z.G.; Zhou, Y.Y.; Zhang, C.Y.; Huang, Y.; Xu, M. Application of nano illite/smectite clay for adsorptive removal of metals in water. Res. Environ. Sci. 2016, 29, 115-123. [CrossRef]

21. Sakthivel, S.; Venkatesan, V.; Krishnan, B.; Pitchumani, B. Influence of suspension stability on wet grinding for production of mineral nanoparticles. Particuology 2008, 6, 120-124. [CrossRef]

22. Bao, S.D. Soil Agricultural Chemistry Analysis, 3rd ed.; China Agricultural Press: Beijing, China, 2000; pp. 152-176, ISBN 9787109066441.

23. Dawodu, F.A.; Akpomie, K.G. Simultaneous adsorption of $\mathrm{Ni}(\mathrm{II})$ and $\mathrm{Mn}$ (II) ions from aqueous solution unto a Nigerian kaolinite. J. Mater. Res. Technol. 2014, 3, 129-141. [CrossRef]

24. Lagergren, S. Zur theorie der sogenannten adsorption gelöster stoffe (about the theory of so-called adsorption of soluble substances); Kungliga Svenska Vetenskapsakademiens (Royal Swedish Academy of Sciences): Stockholm, Sweden, 1898; pp. 1-39.

25. Ho, Y.S.; McKay, G. Pseudo-second order model for sorption processes. Process Biochem. 1999, 34, 451-465. [CrossRef]

26. Langmuir, I. The adsorption of gases on plane surfaces of glass, mica and platinum. J. Am. Chem. Soc. 1918, 40, 1361-1403. [CrossRef]

27. Freundlich, H.M.F. Über die adsorption in lösungen. Z. Phys. Chem. 1906, 57, 385-470. [CrossRef]

28. Jiang, M.Q.; Wang, Q.P.; Jin, X.Y.; Chen, Z.L. Removal of Pb(II) from aqueous solution using modified and unmodified kaolinite clay. J. Hazard. Mater. 2009, 170, 332-339. [CrossRef] [PubMed]

29. Olgun, A.; Atar, N. Equilibrium, thermodynamic and kinetic studies for the adsorption of lead (II) and nickel (II) onto clay mixture containing boron impurity. J. Ind. Eng. Chem. 2012, 18, 1751-1757. [CrossRef]

30. Campo, M.D.; Bauluz, B.; Nieto, F.; Papa, C.D.; Hongn, F. SEM and TEM evidence of mixed-layer illite-smectite formed by dissolution- crystallization processes in continental Paleogene sequences in northwestern Argentina. Clay Miner. 2016, 51, 723-740. [CrossRef]

31. Li, Y.J.; Zeng, L.; Zhou, Y.; Wang, T.F.; Zhang, Y.J. Preparation and Characterization of Montmorillonite Intercalation Compounds with Quaternary Ammonium Surfactant: Adsorption Effect of Zearalenone. J. Nanomater. 2014, 2014. [CrossRef]

32. Deng, L.L.; Yuan, P.; Liu, D.; Liu, Z.W. Effects of microstructure of clay minerals, montmorillonite, kaolinite and halloysite, on their benzene adsorption behaviors. Appl. Clay Sci. 2017, 143, 184-191. [CrossRef]

33. Krishna, G.B.; Susmita, S.G. Pb(II) uptake by kaolinite and montmorillonite in aqueous medium: Influence of acid activation of the clays. Colloid Surf. A 2006, 277, 191-200. [CrossRef]

34. Nir, S.; Undabeytia, T.; Dana, Y.; Yasser, E.; Polubesova, T.; Serban, C.; Rytwo, G.; Lagaly, G.; Rubin, B. Optimization of adsorption of hydrophobic herbicides on montmorillonite presorbed by monovalent organic cations: Interaction between phenyl rings. Environ. Sci. Technol. 2000, 34, 1269-1274. [CrossRef]

35. Li, J.S.; Xue, Q.; Wang, P.; Li, Z.Z. Effect of lead (II) on the mechanical behavior and microstructure development of a Chinese clay. Appl. Clay Sci. 2015, 105-106, 192-199. [CrossRef]

(C) 2018 by the authors. Licensee MDPI, Basel, Switzerland. This article is an open access article distributed under the terms and conditions of the Creative Commons Attribution (CC BY) license (http://creativecommons.org/licenses/by/4.0/). 